UDC 821

DOI https://doi.org/10.32838/2710-4656/2021.4-3/03

Taghiyeva K. A.

Azerbaijan State Agrarian University

\title{
PRECEDENT ERGONYMS OF GANJA AS A CARRIER OF CULTURAL INFORMATION
}

The article examines ergonyms of Ganja city as precedent names. It analyzes the development of precedent ergonomics and their role as a carrier of cultural information. The article emphasizes that ergonyms have become a part of the culture of the people in the modern world, an indicator of the functional capabilities of its language and are conditioned by the national and cultural traditions of the people.

Precedent names are units that reflect the national cultural heritage and history of each nation. The precedent name, which is closely related to its denotation, is able to present the image formed in the mind of a certain linguist. Different onomastic categories can be precedent names. Special names have a special place in the culture of the people, they reflect the specifics of national consciousness. The broad lexical background of specific names is defined as the totality of associations with national culture. The sociocultural background surrounding the names is very important in understanding these units. Precedent names are also units common to all members of a particular linguoculture.

The urgency of the study is due to insufficient study of precedent names, especially precedent ergonyms. Although precedent names have been studied by a number of scholars, this topic is still overlooked by linguists in Azerbaijani onomastics.

The article discusses ergonyms as precedent names. The ergonyms in question are also related to precedent toponyms (specifically the Ganja toponym in the article). The city of Ganja, the cradle of ancient culture, has played an irreplaceable role in the development of socio-economic, political and cultural life of Azerbaijan. Ganja ergonomics consists mainly of associative-figurative units reflecting the culture and background information of the nominee. Among these names are onyms given in connection with a person and location.

The main purpose of the study is to characterize the development potential of precedent ergonyms. The object of research is the national cultural specifics of precedent ergonyms, the subject is the features of their development. Descriptive, observational and semantic analysis methods were used in the research. The research allows to reveal the peculiarities of the development of precedent names in ergonyms. As a result of the research, it becomes clear that the study of the design features of precedent ergonyms is relevant and interesting, as well as that they can provide clear and meaningful information.

Key words: linguoculturology, precedent, special name, precedent name, ergonym.

Precedent names are units that reflect the national cultural heritage and history of each nation. The issue of precedent in linguistics has been analyzed in the works of D.B. Gudkov, A.V. Superanskaya, Y.N. Karaulov, Y.M. Lotman, Y.A. Sorokin, V.V. Krasnykh, D.I. Yermolovich and others. "Precedent name is the name of a personal, representative precedent text or precedent situation and the status of the component of the cognitive base that corresponds to the linguistic and cultural context (D.I. Yermolovich, A.V. Superanskaya, D.B. Gudkov)" [10, c.4]. According to researchers (for example, Y.N. Karaulov, A.V. Zanadvorova, G.G. Slishkin) who consider the precedent to be a feature of linguistic phenomena (precedent text, situation, name), these phenomena arise through the cultural fund of world or national history and are recognized by members of society at the national or international level. In the theory of precedent "A summary definition of the term "precedent phenomenon" (text / quotation, situation, name, statement) is given, which is significant for a particular person in cognitive and emotional relations, which has a supra-personal character, i.e. well known to the wider environment of this person" [4, p. 216].

Language reflects the national landscape of the world, it contains a system of values, the main function of which is the transmission of culture and traditions from generation to generation.

Linguoculturology, which is the relationship between language and culture, can be considered an independent direction in modern linguistics. Linguoculturology, which studies the "worldview formed through the national language", has its 
own subject and language and culture, which are in dialogue, interaction [8, p. 9]. It referred to the "learning of language as a cultural phenomenon" $[11, \quad$ p. 19], "studying the interrelationships and interactions of cultures and languages in its functioning and reflecting this process as a whole structure in the unity of linguistic and non-linguistic content with the help of systematic methods and cultural methods", "it is aimed at the study of linguistic and non-linguistic (cultural) content in a unified manner by systematic methods and in terms of modern priorities, as well as a system of norms and universal cultural instructions" [3, p. 37].

In addition, linquoculturology as "discipline, studying the manifestation, reflection and fixation of cultures in language and discourse [5, p. 12], at the same time, "has a brightly expressed interdisciplinary character, integrates different knowledge of the humanities. For modern linguistics interdisciplinary researches are the most characteristic and demanding" [2]. The development of linguocultural orientation is conditioned by the attempt to understand the phenomenon of culture as a specific form of human and social existence in the world. This field studies the manifestations of the culture of the people, which are reflected and identified in the language.

"Culturally significant information is stored and transmitted by means of proverbs, sayings, phraseological expressions, winged expressions, and common and precedent phenomena" [7].

Precedent phenomena, especially precedent names, are signs of national and world culture.

Special names have a special place in the culture of the people, they reflect the specifics of national self-consciousness. The broad lexical background of special names is defined as a set of associations with national culture. The sociocultural background surrounding the names is very important in understanding these units. Precedent names are also units common to all members of a particular linguoculture. As you know, a proper name has 3 types of information: speech, language, and encyclopedic. Precedent names are distinguished from other onyms by the richness of encyclopedic information. This allows precedent names to provide cultural, historical and social information.

The precedent name, which is closely related to its denotation, is able to present the image formed in the mind of a certain linguist. Different onomastic categories can be precedent names. Some studies even suggest that precedent onyms be identified as a separate group when classifying proper names.
"At the present stage, researchers distinguish the following groups of onyms, which serve as sources of precedence: 1) anthroponyms; 2) place names; 3 ) the names of artistic or other works created by the intellectual labor of a person; 4) chrononyms; 5) the names of business objects; 6) the names of the ships; 7) animal nicknames [9, p. 85-99]. Ergonyms have a special place in this classification as a type of special names.

Ergonyms - "special names of people's business associations" [1, p. 146] - has already become part of the culture of the people in the modern world, an indicator of the language situation and the functional capabilities of the language of a particular country. Ergonyms differ from other onyms by their specific features, characterized by special onomastic regularities. The national-cultural specificity of ergonyms is reflected in the fact that, although they have an international character, they reflect the national culture, as it is conditioned by the national-cultural traditions of the people. This is fully clarified when harmonizing ergonomics with national cultural concepts.

Ergonyms are traditionally considered to be part of a system of onyms of one or another linguocultural aspects. Itis known that the sum of ergonyms and typical contexts in which they are used forms an ergonomic space. This space, in our opinion, has some universal parameters, which is due to the similar characteristics of the objects referred to. In this case, each ergonym as an element of ergonomic space, and the space itself has the characteristics defined by a specific linguoculture. In addition, the system of ergonomics is determined by the regional descriptions of one or another linguoculture.

The city of Ganja, the cradle of ancient culture, has played an irreplaceable role in the development of socio-economic, political and cultural life of Azerbaijan. The city is the center of the historical region of Arran. The name of this region of Azerbaijan has changed several times. So, in the period from 1804 to 1918 it was called Elizavetpol, from 1918 to 1935 it was again called Ganja, in 1935 it was renamed Kirovabad (in honor of S. Kirov), and in 1989 its historical name was returned again. Speaking about the history of the city, it can be briefly mentioned that it is a socio-economic and cultural center. Ganja, like other cities of Azerbaijan (Gabala, Nakhchivan, Sheki, Shamakhi, etc.), was a settlement with a beautiful geographical landscape and was gradually formed as a city. After Barda, the center of the Aran khanate, Ganja played an important role in international trade and was one of the places where caravans often 
passed and stayed. In the IX-X centuries it was the capital of the Shaddadids. At the beginning of the XII-XIII centuries, as the capital of the Atabey state, Ganja gained great fame not only within the country, but also abroad with its products. In the 20th century, Ganja was the temporary capital of independent Azerbaijan, established in 1918 for a short time. The city of Ganja was selected as the "European Youth Capital" in 2016, and the "Capital of Culture" of the Commonwealth of Independent States in 2017. Currently, Ganja is the second largest city in Azerbaijan.

Ganja ergonomics consists mainly of associativefigurative units reflecting the culture and background information of the nominee. Among these names are onyms given in connection with a person and location.

Ganja oikonym is found as an integral part of many ergonyms in the city: "Ganja Mall", "Ganja Telecom", "Ganja Cosmetics", Ganja MedicalDiagnostic Center, "Yeni Ganja" Medical Center, Ganja Humanitarian College, Ganja State Puppet Theater, etc.

It is very important to choose a name responsibly. Traditionally, the protection of cultural monuments affects the process of choosing ergonomics. The great Azerbaijani poet and thinker Nizami Ganjavi laid the foundation of a series of poems called "Khamsa" ("Five") in Eastern literature, in the Turkic-Muslim world. After the great master, the creation of "Khamsa" became a tradition in Eastern literature, and poets of many nations created the poems "Five". The whole life and rich literary activity of the artist is connected not only with one of the largest cities of Azerbaijan and the Caucasus, but also with Ganja, which is known as an important cultural center of the Middle East. "Khamsa" is one of the rare pearls of the world literature, which is reflected in the names of objects in the city, for example: "Khamsa Mall", "Khamsa Park" (trade objects) and so on.

Local toponyms are also reflected in ergonyms. "Mahsati Garden" in Ganja is connected with two ergonomics: 1) Mahsati Ganjavi Center (cultural center); 2) "Mahsati Baghi" cafe. These onomastic units are associated with the name of the first famous Azerbaijani poet, the first female chess player, the first prominent female musician and, most likely, the first female composer Mahsati Ganjavi, who lived in the late eleventh and early twelfth centuries. In front of the Mahsati Ganjavi Center there is a garden named after him, and in the garden there is a cafe "Mahsati Baghi".

We can give an example of the localization of the object, i.e. the street where they are located, their position in relation to the nominee, as well as the ergonomic "Shah Ismail Khatai Shop 95" to the names referring to other toponyms. There are many objects in Azerbaijan named after Shah Ismail Khatai, the founder of the Safavid state, who translated Azerbaijani Turkish into the state language and did great work for the political, social, economic and cultural development of the country. This ergonym in Ganja is also located on the street named after him and has an unusual structure.

According to S.L. Kushneruk, precedent names, on the one hand, are closely related to their carrier and contain information about him, on the other hand, have relative independence and are able to attribute certain features to objects. The researcher notes that the precedent name has a certain meaning and shows that the meaning consists of the following components: "Nominative value - names the object indicated by the name; denotative meaning - includes typical features reflecting cultural and historical information associated with the primary referent and often recorded in the dictionaries of culture (M.A. Solovyov); and the significative meaning associated with the presence of a conceptual component in the name" [6, p. 32].

Based on this classification, we can give relevant examples: the name of the restaurant "Goygol" corresponds to the nominative meaning. This ergonym is connected with my toponym - Goygol. From the day of its creation, the name of Goygol is mentioned in poems and songs as a symbol of beauty. This hydronym is also used in various onomastic fields, including ergonomics, by transonymization.

We can attribute the ergonim "Khan's garden" / "Khan Baghi" to denotative names. The most famous and largest park in Ganja is Khan Baghi. Khan's garden was built in 1700. The total area is 6 hectares. One of the oldest parks in the Caucasus, Khan Baghi, which historically existed as a resting place for khans, is named after the ruler of Ganja Ziyad khan. "Khan Baghi" is famous throughout the country for its rich flora. The name of this garden is reflected in the name of "Khan Baghi" cafe.

Ganja is distinguished by its unique sweets and dishes, for example: Gancə dovğast, Gəncə katəsi, Ganco paxlavasi and etc. In addition, other blessings of Ganja are popular (for example, greens, cheese, fruits, etc.). Commercial facilities selling these goods exist in many cities of Azerbaijan and are known as "Ganca nematlari", "Gənca matbaxi", "Gənca tandiri". In our opinion, it would be correct to attribute these ergonyms to names with signifiable meaning. 
Let's get acquainted with some of the other precedent ergonomies given to commercial objects of Ganja city. Usually, precedent ergonomies are given in connection with the nature of the operation of objects. For example, the children's clothing store "Buratino" - a woodcutter who has an unusual adventure in search of a golden key, everyone is familiar with the story of Buratino and his friends. The transfer of Buratino, the favorite hero of children's fairy tales, to such an object is a successful step. Titanic Fish Restaurant - The name of this famous ship, which still resonates around the world, is usually given to seafood in many places. It can be considered as a name that creates an emotional relationship in the addressee. The fact that the pharmacy "Aybolit" - the hero of Korney Chukovsky the name of the healing institution of the benevolent doctor Aybolit - has a positive association. Simurg Company - Simurg is a legendary bird mentioned in the mythology of the peoples of the East. In Azerbaijani folklore, the Simurg bird is usually described as a kind bird that helps people and fights against evil forces together with the hero. The Simurg bird usually plays a supporting role. It is also noteworthy that the company engaged in passenger transportation was given this name.

The study allowed discovering specific features of the use of precedent names in ergonomics; to discover that precedent ergonomics allow the transmission of information in a bright, concise and accessible form. The study revealed: 1) the study of the properties, functioning of precedent ergonomics is relevant and interesting; 2) active use in ergonomic space Ganja precedent names, rising to the names of heroes, fairy tales, myths, movies, cartoons; 3) they attract the attention of city residents, potential customers, offered and advertised topics or in the form of a city service facility.

\section{References:}

1. Adilov M., Verdiyeva Z., Ağayeva F. İzahlı dilçilik terminləri lüğəti. B.: Elm və Təhsil, 2020. $656 \mathrm{~s}$.

2. Белозерова А. В. Лингвокультурология как лингвистическая дисциплина. Современные проблемьл науки и образования. 2013. № 1. URL: http://www.science-education.ru/ru/article/view?id=7681.

3. Воробьев В. В. Лингвокультурология: теория и методы. Москва : Российский ун-т дружбы народов, 1997. 332 c URL: https://www.twirpx.com/file/1377206/.

4. Караулов Ю. Н. Русский язык и языковая личность. Москва : Наука, 1987. 264 с.

5. Красных В. В. Этнопсихолингвистика и лингвокультурология: Лекционный курс. Москва : Гнозис, 2002. 284 c. URL: https://www.twirpx.com/file/213813/.

6. Кушнерук С. Л. Сопоставительное исследование прецедентных имён в российской и американской рекламе : дисс. ... канд. филол. наук. Екатеринбург, 2006. URL: https://www.twirpx.com/file/2830776/.

7. Лобан Т. В. Прецедентный феномен как объект исследования. Веснік Мазырскага дзяржсаўнага педагагічнага ўніверсітэта імя І.П. Шамякіна. 2016. URL: https://cyberleninka.ru/article/n/pretsedentnyy-fenomen-kak-obekt-issledovaniya.

8. Маслова В. А. Лингвокультурология : учеб. пособие для студ. высш. учеб. заведений. Москва : Академия, 2001. 183 c. URL: https://www.twirpx.com/file/2211117/.

9. Нахимова Е. А. Прецедентные онимы в современной российской массовой коммуникации: теория и методика когнитивно-дискурсивного исследования: монография. Екатеринбург : ГОУ ВПО «Урал. гос. пед. ун-т», 2011. 313 с.

10. Поветьева Е. В. Прецедентное имя как феномен интертекстуальности в англоязычном художественном дискурсе. АКД. Волгоград, 2014. URL: https://vspu.ru/sites/default/files/disfiles/avtoreferat_povetevoy_e.v..pdf.

11. Rəhimov M. N. Müasir Azərbaycan dilinə tərcümədə linqvokulturoloji fərqlilik faktoru (amerikanizm-frazeologizmlərin dilimizdəki semantik adekvatlıq probleminə dair). Bakı Universitetinin Xəbərləri, Humanitar elmlər seriyası. 2015. № 1. S. 19-24.

\section{ТаГієва К. А. ПОПЕРЕДНІ ЕРГОНІМИ ГЯНДЖИ ЯК НОСІЯ КУЛЬТУРНОЇ ІНФОРМАЦІї}

У статті розглядаються ергоніми міста Гянджа як прецедентні назви. Він аналізує розвиток попередньої ергономіки та їх роль як носія культурної інформації. У статті підкреслюється, щяо ергоніми стали частиною культури людей у сучасному світі, показником функціональних можливостей його мови та зумовлені начіональними та культурними традиціями народу.

Прецедентні імена - ие одиниці, щзо відображають національну культурну спадщину та історію кожного народу. Назва прецеденту, яка тісно пов'язана з його позначенням, здатна представити образ, сформований у свідомості певного лінгвіста. Імена прецедентів можуть бути різні ономастичні категорії. Спечіальні імена посідають особливе місие в культурі народу, вони відображають специфіку національної свідомості. Широкий лексичний фон конкретних назв визначається 
як сукупність асоиіацій з національною культурою. Соџіокультурне походження навколо назв є дуже важливим для розуміння ичих одинищь. Прецедентні імена - це також одиниці, загальні для всіх представників певної лінгвокультури.

Актуальність дослідження зумовлена недостатнім вивченням назв прецедентів, особливо прецедентних ергонімів. Незважаючи на те, що імена прецедентів вивчали низка вчених, ия тема все ще залитається поза увагою лінгвістів в азербайджанській ономастииі.

У статті розглядаються ергоніми як прещедентні назви. Розглянуті ергоніми також пов'язані з прецедентними топонімами (зокрема, топонім Гянджі в статті). Місто Гянджа, колиска давньої культури, зіграло незамінну роль у розвитку сочіально-економічного, політичного та культурного життя Азербайджану. Ергономіка Гянджі складається в основному з асоиіативно-образних одиниць, щзо відображають культуру та вихідну інформацію кандидата. Серед циих назв є оніми, подані у зв 'язку з особою та місиезнаходженням.

Основною метою дослідження є характеристика потенціалу розвитку попередніх ергонімів. Об'єктом дослідження є національна культурна спеиифіка попередніх ергонімів, предметом - особливості їхнього розвитку. У дослідженні використовувались описові, спостережливі та семантичні методи аналізу. Дослідження дозволяє виявити особливості розвитку прещедентних імен в ергонімах. У результаті досліджсння стає зрозумілим, що вивчення конструктивних особливостей попередніх ергонімів с актуальним та цікавим, а також що вони можуть надати чітку та змістовну інформацію.

Ключові слова: лінгвокультурологія, прецедент, спеціальна назва, прещедентна назва, ергонім. 